\title{
Pemanfaatan Protein Hewani Melalui Pengolahan Nugget Ikan Tuna Di Desa Malalanda Kecamatan Kulisusu Kabupaten Buton Utara
}

\author{
Febriana Muchtar ${ }^{1}$, Hartati Bahar ${ }^{2}$ dan Hariati Lestari ${ }^{3}$ \\ ${ }^{123}$ Fakultas Kesehatan Masyarakat \\ Universitas Halu Oleo \\ febrianamuchtar9@uho.ac.id
}

\begin{abstract}
Abstrak - Desa Malalanda Kecamatan Kulisusu merupakan salah satu Kecamatan di Kabupaten Buton Utara dengan sektor perikanan sebagai sektor unggulan, dan merupakan wilayah sentra pengolahan ikan asap. Potensi perikanan yang dimiliki dapat memberikan manfaat finansial bagi penduduk setempat. Ikan memiliki potensi zat gizi yang sangat penting, khususnya sebagai sumber protein. Telah terbukti bahwa ikan merupakan salah satu sumber protein hewani yang berkualitas. Tujuan pelaksanaan Kegiatan Pengabdian pada masyarakat di Desa Malalanda Kecamatan Kulisusu adalah memberikan pengetahuan tentang diversifikasi pangan sumber protein hewani berbahan dasar ikan tuna dan meningkatkan nilai tambah produk olahan ikan tuna. Metode pelaksanaan pengabdian melalui penyuluhan pembuatan nugget ikan tuna yang diawali dengan observasi dan sosialisasi. Pelaksanaan kegiatan ini khususnya ditujukan untuk ibu rumah tangga dan remaja putri. Hasil yang diperolah dari kegiatan pengabdian masyarakat adalah bertambahnya pengetahuan tentang diversifikasi produk berbahan baku ikan tuna. Kegiatan pengabdian masyarakat berjalan lancar dan diikuti dengan antusias oleh seluruh peserta.
\end{abstract}

Kata Kunci: Protein Hewani, Nugget, Ikan Tuna

\section{PENDAHULUAN}

Kabupaten Buton Utara merupakan daerah yang mempunyai potensi sumberdaya mempunyai potensi sumberdaya laut dan perikanan yang beranekaragam. Hal ini dikarenakan letak Kabupaten Buton Utara pada posisi yang strategis karena berhadapan dengan laut Banda sebagai daerah tangkapan ikan dalam peta perikanan nasional. Desa Malalanda merupakan salah satu desa di Kecamatan Kulisusu Kabupaten Buton Utara. Terletak di wilayah pesisir memberikan peluang untuk menjadikan perikanan dan produk perikanan menjadi salah satu sektor penting dalam perekonomian masyarakat di desa Malalanda guna meningkatkan kesejahteraan masyarakatnya.

Data Kabupaten Buton Utara dalam Angka Tahun 2018 yang dikeluarkan oleh Badan Statistik Buton Utara bahwa produksi perikanan tangkap paling besar pada kecamatan Kulisusu yaitu 3791,18 ton pada tahun 2016 dan 4.061,54 ton pada tahun 2019. Data Produksi Ikan semester 1 Tahun 2019 yang dipeoleh dari Dinas Perikanan Kabupaten Buton Utara produksi ikan Tuna yang banyak ditangkap adalah ikan Tuna Sirip Kuning yaitu sebanyak $16.242 \mathrm{~kg}$.

Berdasarkan hasil informasi lapangan dan observasi, pengolahan ikan tuna di Desa Malalanda Kecamatan Kulisusu sangat terbatas. Selama ini ikan tuna yang ditangkap dijual dalam bentuk segara atau diolah menjadi ikan asap. Dalam bentuk segar ikan tuna dijual dari nelayan pemancing ke pengumpul seharga $\mathrm{Rp}$. 7.000 - Rp. 8.000/ kg dan ikan asap dijual dengan herga Rp. 20.000-Rp. 30.000/ekor (tergantung dari ukuran ikan tuna asap).

Jika dikaji Desa Malalanda Kecamatan Kulisusu memiliki potensi sumberdaya dalam pengolahan ikan termasuk ikan tuna, namun hingga saat ini pengetahuan masyarakat tentang pengolahan hasil periakanan masih sangat minim. Hal ini dapat dilihat dengan produk olahan ikan tuna yang umum dijual adalah ikan tuna asap. Potensi perikanan yang begitu besar hanya diolah menjadi satu jenis produk olahan dan dilakukan dalam skala industri rumah tangga dengan metode pengasapan secara tradisional. Produk olahan ikan tuna asap ini biasanya hanya untuk memenuhi kebutuhan pasar lokal. 
Pada prinsipnya usaha diversifikasi pengolahan hasil perikanan bertujuan untuk meningkatkan daya simpan hasil perikanan, memberikan beragam produk pilihan pada konsumen serta meningkatkan nilai jualnya sehingga akan meningkatkan pendapatan pengolah ikan. Dengan demikian usaha pengolahan makanan berbahan baku ikan dapat menjadi salah satu sektor yang diharapakn dapat meningkatkan pertumbuhan ekonomi melalui peningkatan pelung bekerja dan meningkatkan pendapatan.

Menurut Muqsit dkk (2016) dalam Ekayanan dkk (2017) bahwa jenis tuna besar yang selama ini banyak dijumpai di Indoniesa adalah tuna sirip kuning (Thunnus albacares), tuna mata besar (Thunnus obesus), albakora (Thunnus alalunga) dan tuna sirip biru (Thunnus maccoyii). Menurut Asrawaty dan If'all (2018) bahwa nugget adalah salah satu produk olahan daging yang terbuat dari daging giling yang dicetak dalam bentuk potongan empat persegi. Potongan ini kemudian dilapisi dengan tepung berbumbu (battered dab breaded). Produk nugget dapat dibuat dari daging sapi, ayam ikan dan lain-lain.

Berdasarkan latar belakang masalah tersebut maka kami tertarik untuk melakukan penyuluhan tentang pengolahan ikan tuna menjadi nugget, sebagai salah satu alternatif penganekaragaman hasil olahan ikan tuna.

\section{METODE PELAKSANAAN}

Pengabdian Kepada Masyarakat ini merupakan program yang dilaksanakan oleh tim dosen Fakultas Kesehatan Masyarakat, Universitas Halu Oleo Kendari. Kegiatan pengabdian berupan penyuluhan tentang diversifikasi hasil perikanan khususnya ikan tuna menjadi nugget ikan tuna.

Metode pelaksanaan kegiatan pengabdian ini dilakukan dengan langkah-langkah pelaksanaan sebagai berikut :

1. Observasi. Pelaksanaan diawali dengan observasi lapangan tentang produk olahan ikan tuna yang terdapat di Desa Malalanda.

2. Sosialisasi Produk Nugget Ikan Tuna. Tahap ini dilakukan dengan tujuan memperkenalkan kepada masyarakat Desa Malalanda tentang produk olahan ikan tuna lainnya, yaitu nugget ikan tuna.
3. Penyuluhan. Penyuluhan dilakukan dengan cara mempraktekan cara pembuatan nugget ikan tuna kepada masyarakat Desa Malalanda, khususnya ibu rumah tangga dan remaja putri. Pada tahap ini, kami menginfromasikan tentang bahan yang digunakan, alat serta tahap pembuatan nugget ikan tuna. Dalam pelaksanaannya peserta diberikan waktu untuk langsung mempraktekan cara pembuatan nugget ikan tuna.

\section{HASIL DAN PEMBAHASAN}

Kegiatan Pengabdian Kepada Masyarakat di Desa Malalanda berupa kegiatan penyuluhan tentang cara pembuatan nugget ikan tuna. Kegiatan ini dilakukan untuk diversifikasi produk olahan ikan tuna serta melatih masyarakat agar lebih kreatif dan inovatif dalam memanfaatkan potensi lokal, khususnya hasil perikanan untuk meningkatkan nilai guna hasil perikanan.

Pelaksanan kegiatan pengabdian ini dilakukan dengan beberapa tahap, yaitu :

1. Observasi. Tahap ini dilakukan sebagai langkah awal untuk mengetahui potensi yang terdapat di Desa Malalanda. Observasi dilakukan selama 2 hari, yaitu pada tanggal 13 dan 14 Januari 2020. Observasi dilakukan dengan pengamatan langsung di desa Malalanda serta melakukan pencarian data potensi ikan tuna di Kecamatan Kulisusu pada Dinas Perikanan Kabupaten Buton Utara. Hasil Observasi diperoleh bahwa selama ini ikan tuna hanya diolah menjadi ikan asap. Adapun berdasarkan data yang diperoleh, terdapat potensi bahan baku produk olahan ikan tuna yang cukup besar. Namun keterbatasan pengetahuan masyarakat sehingga potensi tersebut belum dimanfaatkan secara maksimal.

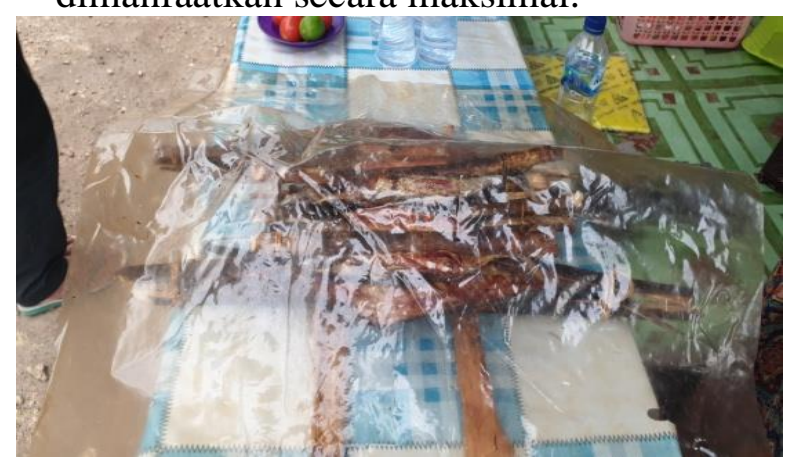

Gambar 1. Ikan Tuna Asap 
2. Sosialisasi Nugget Ikan Tuna. Tahap ini dilakukan dengan tujuan untuk memperkenalkan produk olahan ikan tuna lainnya yaitu nugget ikan tuna. Selain itu memberikan informasi langsung kepada masyarakat bahwa akan dilakukan kegiatan penyuluhan tentang cara pembuatan nugget ikan tuna.

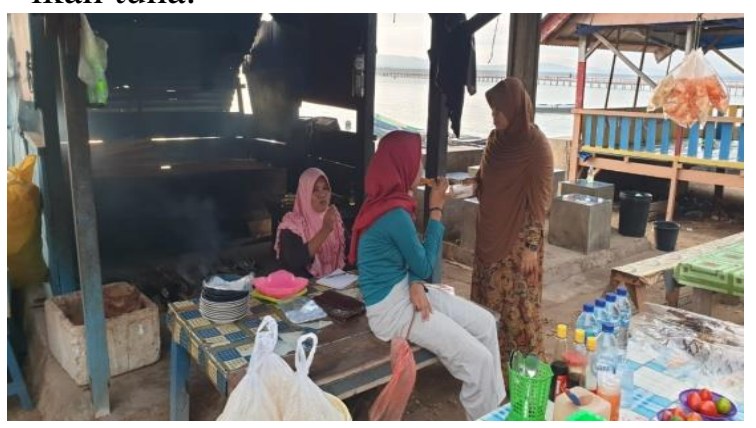

Gambar 2. Pengenalan Nugget Ikan Tuna

3. Penyuluhan Cara Pembuatan Nugget Ikan Tuna. Tahap ini melakukan tatap muka dengan masyarakat sekaligus mengajarkan kepada masyarakat tentang cara pembuatan nugget ikan tuna disertai cara menyimpan dan mengawetkan serta cara pengemasan jika nantinya akan dibuat menjadi produk komersil. Penyuluhan ini dilakukan dengan mempraktekan cara pembuatan nugget ikan tuna.

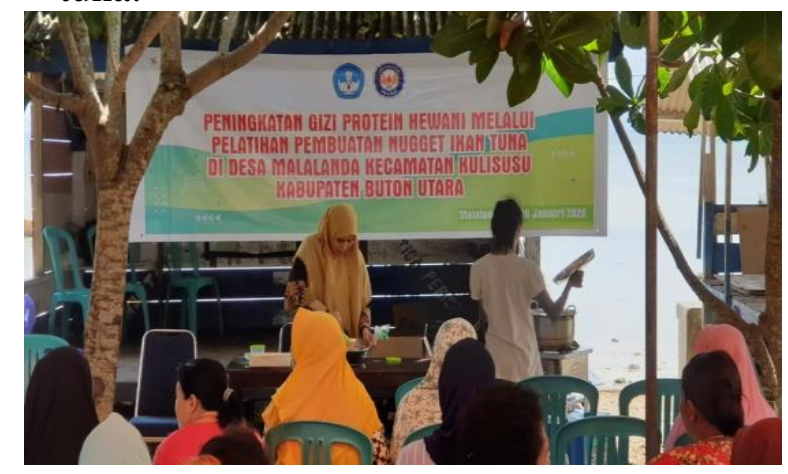

Gambar 3. Praktek Pembuatan Nugget Ikan Tuna

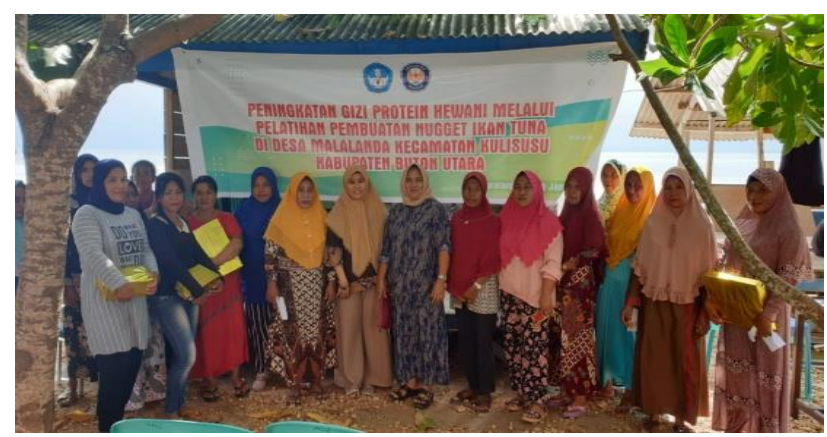

Gambar 4. Beberapa Peserta Penyuluhan Pembuatan Nugget

Ikan Tuna

\section{KESIMPULAN}

Masyarakat desa Malalanda Kecamatan Kulisusu khususnya para ibu rumah tangga dan remaja putri sangat antusias mengikuti penyuluhan cara pembuatan nugget ikan tuna. Disamping itu Pemerintah Desa Malalanda sangan mendukung kegiatan Pengabdian ini.

\section{SARAN}

Kreativitas dan inovasi sangat dibutuhkan untuk memaksimalkan pemanfaatan potensi perikanan lokal di Desa Malalanda Kecamatan Kulisusu Kabupaten Buton Utara.

\section{UCAPAN TERIMA KASIH}

Ucapan terima kasih kami haturkan kepada Pemerintah Desa Malalanda, Kecamatan Kulisusu Kabupaten Buton Utara yang bersedia menerima kami serta mendukung pelaksanaan kegiatan Pengabdian Kepada Masyarakat ini.

\section{DAFTAR PUSTAKA}

Asrawaty dan If'all. 2018. Perbandingan Berbagai Bahan Pengikat dan Jenis Ikan Terhadap Mutu Fish Nugget. Jurnal Galung Tropika, 7 (1).

Badan Pusat Statistik Kabupaten Buton Utara. 2019. Kabupaten Buton Utara Dalam Angka Tahun 2018.

Ekayana, I. M., I Wayan Gede A K, Abd. Rahman A, Irwan J dan Dian N. 2017. Hubungan Hasil Tangkapan Ikan Tuna Selama Februari-Maret 2016 Dengan Konsentrasi Klorofil-a dan SPL dari Data Pengideraan Jauh Di Perairan Selatan Jawa-Bali. Journa of Marine and Aquatic Sciences 3 (1).

Firdaus, M. 2018. Profil Perikanan Tuna dan Cakalang di Indonesia. Buletin Ilmiah Marina Sosial Ekonomi Kelautan dan Perikanan. Volume 4, No. 1.

Hardoko, Eddy S, Titik D. S dan Alfin A. 2017. Karakteristik Nugget Pindang IkanAmpas Tahu yang ditambah Tepung Tulang Ikan Sebagai Sumber Kalsium. Jurnal Sains dan Teknologi, Volume 1, No. 1.

Hendrawati, S dan Irfan Z. 2017. Gambaran Konsumsi Ikan pada Keluarga dan Anak PAUD RW 07 Desa Cipacing. Jurnal Pengabdian Kepada Masyarakat. Volume 1, No. 2.

Junita, D dan Dini Wulan Dari. 2019. PKM Gemar Makan Ikan untuk Kecerdasan 
Anak Sekolah di SDN 82/IV Sejinjang Kota Jambi. Jurnal Abdimas Kesehatan (JAK) Vol 1, No. 1. 